\title{
Fritak og religiøse spenninger i skolen
}

Av Christian Lomsdalen

Fritaksretten $i$ grunnskolen gjor at elever kan unngå a delta i opplaeringsaktiviteter $i$ skolen som oppleves som praktisering av eller tillutning til en annen religion eller et annet livssyn, eller som med bakgrunn $i$ det samme oppleves som problematisk. Fritaksretten utgjor på flere måter et paradoks, og det foreligger veldig lite informasjon om hvordan den praktiseres ute i skolen. I denne artikkelen drofter jeg klagesaker og henvendelser til statsforvalterembetene opp mot teorien om skolen som et uenighetsfellesskap. Jeg viser hvordan noen saksområder er problematiske for utvalgte grupper i skolen ut fra egen tro eller eget livssyn, eller som for dem oppleves som deltagelse i annen tro og livssyn.

Nøkkelord: KRLE, religionsdidaktikk, fritaksrett, opplæringsloven, praksisfeltet, grunnskolen

CHRISTIAN LOMSDALEN (f. 1985), lektor ved Metis videregående skole og Universitetslektor II ved Universitetet i Bergen. Lars Hilles gate 17, 5008 Bergen. E-post: c@Imsdln.no.

\section{IN N LE DNING}

Etter kritikken mot Norge i FNs menneskerettighetskomite i 2004 ble det iverksatt tiltak for å fjerne muligheter for tilsvarende kritikk i fremtiden. Ett av tiltakene var å skille fritaksretten ut som en egen paragraf i Opplæringsloven (\$2-3a) istedenfor å være en del av religionsfagsparagrafen (\$2-4). Med denne endringen ble den gjort gjeldende for hele grunnskolen, men den ble samtidig rammet inn slik at en ikke kunne få fritak for kunnskapsinnhold i læreplanen. Det er begrenset med kunnskap om hva som er praksis ute i skolene og hvordan dette har påvirket undervisningen, ettersom det ikke har skjedd noen evaluering av faget siden 2000 (St.meld.nr. 32 (2000-2001)). Utskillelsen av fritaksparagrafen var ikke den eneste endringen i forbindelse med kritikken, ettersom faget i 2008 ble endret fra Kristendoms-, religions- og livssynskunnskap (KRL) til Religion, livssyn og etikk (RLE). Det ble videre tatt inn i opplæringsloven og læreplanen at religionsfaget skulle være «objektivt, kritisk og pluralistisk» (Lippe, 2018b, s. 131) ${ }^{1}$.

I denne artikkelen vil jeg se på noen av hovedtrendene som vi finner i det store mangfoldet i saker og henvendelser som kommer inn til statsforvalterembetene $^{2}$ angående fritak med grunnlag i fritaksparagrafen i Opplæringsloven, §2-3a.

1 Den historiske bakgrunnen for endringene vil ikke gjennomgås ytterligere i denne artikkelen, men kan leses om hos for eksempel Lied (2008), Hovdelien (2019), Andreassen (2012) eller von der Lippe (2017).

2 Embetet het «fylkesmann» og «fylkesmannsembetet» ved undersøkelsestidspunktet. Den nye tittelen vil bli benyttet.

Prismet - IKO-Forlaget 2021

Tilgjengelig på https://journals.uio.no/index.php/prismet. Publisert under CC BY-NC 4.0. Fagfellevurdert 
Sakene og henvendelsene består av svært ulike saker, hvor noen er rene informasjonsinnhentingshenvendelser hvor det ønskes informasjon om fritaksordningen generelt eller om regelverket for ulike tilfeller. Det er også saker hvor det klages på skolens ${ }^{3}$ h̊̊ndtering av ulike fritaksønsker eller på gjennomførte opplegg som foresatte eller elev mener de burde ha fått fritak fra. I denne artikkelen er det primære spørsmålet hvordan livssynstilhørighet er knyttet opp mot hva slags klagesaker det er som sendes inn knyttet til fritaksretten, og hvordan funnene kan forstås i lys av Lars Laird Iversens begrep om og forståelse av skolen som uenighetsfellesskap (2017).

Samtidig dokumenterer artikkelen noe av variasjonene i klagesaker og henvendelser som har kommet inn. Det sees blant annet på hva det ønskes fritak fra eller hva henvendelsen dreide seg om, hva problemstillingen var, bakgrunnen til innsender, skoleslag, og geografisk fordeling av saksvariasjonen. Dette er en side ved kunnskapsbasen om norsk skole som har manglet frem til nå, hvor vi har hatt lite, til ingen, informasjon om hvordan fritaksretten i norsk skole har fungert ${ }^{4}$

\section{FRITAKSRETTEN I GRUNNSKOLEN}

Fritaksretten i grunnskolen gir foreldre, og elever over 15 år, en mulighet til å la elever få slippe å delta i opplæringsaktiviteter «som dei ut frå eigen religion eller eige livssyn opplever som utøving av ein annan religion eller tilslutning til eit anna livssyn, eller som dei på same grunnlag opplever som støytande eller krenkjande» (Opplæringsloven §2-3a). Fritaksretten kan sies å være et paradoks. Den er på samme tid ubegrenset siden den gjelder for hele grunnskolen, samtidig som den er begrenset gjennom at eleven ikke kan fritas fra opplæring i fagstoff begrunnet i læreplanmålene i de ulike fagene. Det kan på tross av denne begrensningen innvilges at eleven får undervisningen på en annen måte enn resten av elevene gjennom et alternativt undervisningsopplegg. Det er med andre ord ikke gitt at foreldrene må akseptere en gitt undervisningsmetode selv om de skulle måtte akseptere at deres barn får undervisning $i$ et tema som de oppfatter som problematisk. Fritaksretten er derfor i mange tilfeller noe som gir fritak fra ulike undervisningsaktiviteter, men hvor eleven må få den samme opplæringen gjennom et alternativt, men likeverdig, undervisningsopplegg. Bakgrunnen for fritaksretten i grunnskolen er for å balansere det at Norge har en offentlig fellesskole hvor de fleste av elevene går, samtidig som skolen har et obligatorisk religionsfag for alle elevene: Fritaksretten er historisk knyttet til religionsfaget, og har i ulike former vært en del av norsk skole siden religionsfaget var et konfesjonelt kristendomsfag (Andersland, 2019, s. 6-7), men gjelder i dag for alle fag og situasjoner (Skeie,

3 Når begrepet skolen brukes i denne artikkelen, siktes det til den offentlige skolen.

4 Artikkelen bygger på og videreutvikler et mastergradsarbeid i religionsvitenskap ved Universitetet i Bergen (Lomsdalen 2019). 
2018, s. 47).5 Fritaksretten er regnet som nødvendig med bakgrunn i menneskerettighetene til elevene og foreldrene ut fra forpliktelser Norge har ratifisert $\mathrm{i}$ ulike erklæringer, konvensjoner og tilleggsprotokoller (von der Lippe, 2018a, s. 146). Dette forplikter skolen og det offentlige på å ivareta elevenes og foreldrenes trosfrihet, men også elevenes rett på utdanning og foreldrenes rett til å ta avgjørelser for sine barn og å oppdra dem i egen tro eller eget livssyn (Europarådet, 1952, artikkel 2; von der Lippe, 2017, s. 88-91; von der Lippe, 2018b, s. 131).

Om skolen tar foreldrenes fritaksmelding til følge, må faglærer utarbeide et alternativt opplegg slik at eleven kan nå de samme læreplanmålene som de andre elevene. Hvis skolen finner det nødvendig å avvise fritaksmeldingen, må det gjøres et enkeltvedtak som forklarer bakgrunnen for avgjørelsen (von der Lippe, 2018a, s. 146). Dersom foreldrene velger å ikke godta avslaget, kan det påklages i tråd med ordinær klagegang for enkeltvedtak. En slik klagegang vil innebære at det først påklages til skolen og skoleeier. Ved avslag hos skoleeier eller skole kan det klages videre til statsforvalteren. I noen tilfeller finnes det et eget kommunalt klageorgan som behandler klagen etter avslag hos skole og skoleeier, men før klagen oversendes til statsforvalterembetet (Forvaltningsloven, 1967, §28). ${ }^{6}$

\section{TIDLIGERE FORSKNING}

Det har kun vært en begrenset forskning på fritaksretten. Det var noe fokus på temaet da det daværende KRL-faget ble evaluert ved årtusenskiftet (St.meld.nr. 32 (2000-2001)), men det var før endringen i fritaksretten i 2005. På tross av gjentatte oppfordringer fra nasjonale og internasjonale organisasjoner og institusjoner har det ikke vært gjort noen evalueringer etter endringene etter kritikken i 2004 og dommen som kom i 2007 (von der Lippe, 2018a, s. 160). Det har likevel vært noe forskning på skolegudstjenestene som fenomen. Elisabeth Haakedal, Anne Løvland og Pål Repstad har sett på hvordan gudstjenestene gjennomføres, og elementene som er en del av gudstjenestene (Haakedal, 2000; Løvland og Repstad, 2019). Videre har Olav Hovdelien har sett på rektors valg om å gjennomføre gudstjenester i skoletiden og deltakelse på skolegudstjenester på to ulike steder i landet (Hovdelien, 2011). Det har også vært sett på hvordan skolene praktiserer juleavslutninger, og de refleksjonene som er rundt dette, blant annet av Mina Øverlien og Ole Kolbjørn Kjørven (Øverlien og Kjørven, 2020). Fritaksretten og praktiseringen av den glimrer likevel stort sett med sitt fravær. Det er likevel noen unntak. Blant annet ser Marte Holmeide Dalane kvalitativt på fritak knyttet til musikkundervisningen for et mindre antall muslimske elever i grunnskolen (Dalane, 2014,

5 I forslag til ny opplæringslov er dette foreslått utvidet til hele skoleløpet, inkludert videregående skole hvor fritaket i \$2-3a ikke har vært gjeldende (NOU 2019: 23, s. 35). Det kan likevel argumenteres for at det tidligere har vært en fritaksrett også i videregående, men ikke begrunnet i denne paragrafen (Lomsdalen, 2019, s. 71).

6 For en mer detaljert beskrivelse av saksgangen for fritaksønsker og avslag på fritaksønsker, se side 2 til $4 \mathrm{i}$ Lomsdalen, 2019. 
s. 66) og Hovdelien undersøkte i forbindelse med sin doktorgrad i hvilket omfang rektorer han intervjuet i Oslo og Agder, har mottatt fritaksmeldinger. Hovdeliens undersøkelse dekker tidsrommet 2007 og 2008. De fleste rektorene (57 \%) i undersøkelsen hadde aldri fått noen fritaksmeldinger, og bare $5 \%$ hadde fått over 20 fritaksmeldinger (Hovdelien, 2011, s. 226-227). Fritaksretten var rimelig fersk på dette tidspunktet, noe som nok kan bidra til det lave antallet fritaksmeldinger.

\section{Metode}

Jeg har gjort en datainnsamling med innhenting av saksdokumenter fra alle typer henvendelser som har kommet til statsforvalterembetene i Norge med tilknytning til fritak slik vi finner det i Opplæringsloven $\$ 2-3 a$. Det ble sendt innsynsbegjæringer til alle 16 statsforvalterembetene i Norge i 20187, men sakene og henvendelsene har kommet inn fra og med fritaksretten ble innført i 2005 og frem til innsamlingstidspunktet. Dokumentene ble en del av datamaterialet uavhengig av type henvendelse, om det var et skriftlig spørsmål eller om det var klagesaker. Jeg fikk da et datamateriale bestående av de dokumentene som ble overlevert fra statsforvalterembetene i innsamlingsperioden i 2018. Det ble oversendt til sammen 57 skriftlige saker i denne innsamlingsprosessen. Det samlede datamaterialet ble gjenstand for en kvantitativ innholdsanalyse, med kategorisering av dataene med bakgrunn i geografisk opphav, når saken utspilte seg eller ble sendt inn, hvilke institusjoner som var en del av saken, hva slags type sak det dreide seg om, skoleslag, skolefag, utfallet i/av saken, og den religiøse tilhørigheten til innsender (Lomsdalen 2019). Denne artikkelen analyserer og drøfter den delen av datamaterialet hvor det er en høy grad av angitt livssynstilhørighet på elevene sakene gjaldt, eller der hvor innsender selv oppgav livssynstilhørighet.

Det er noen kjente svakheter med det innsamlede datamaterialet, ved at det er kjent at det ikke representerer det totale bildet av klagesaker og henvendelser til statsforvalterembetene knyttet til fritaksretten, det er noen kjente saker som ikke har vist seg i datamaterialet ${ }^{8}$, men alle dokumenter som ble oversendt fra embetene har blitt gjennomgått..

\section{KORT OM DET INNSAMLEDE DATAMATERIALET}

Det totale innsamlede datamaterialet består av 222 forskjellige dokumenter, og utgjør 57 individuelle henvendelser eller klager. Til sammen var det kommet inn

7 Innsynsbegjæringen ble sendt inn og behandlet før regionreformen, og det var på det tidspunktet 16 statsforvalterembeter i Norge. Oslo og Akershus, Østfold, Oppland, Hedmark, Buskerud, Telemark, Vestfold, Agder, Rogaland, Hordaland, Sogn og Fjordane, Møre og Romsdal, Trøndelag, Nordland, Troms, og Finnmark.

8 Bare to av mer enn tretti henvendelser jeg selv har gjort til statsforvalterembetene som har blitt redegjort for i datamaterialet som ble oversendt som en del av datainnsamlingen (Lomsdalen, 2019, s. 52-53). 
klager til 12 av statsforvalterembetene som omhandler §2-3a i Opplæringsloven. I tabell 1 presenteres det en oversikt over de ulike saksfeltene som har blitt rapportert inn fra hvert enkelt statsforvalterembete. Saksutvalget er for lite til at vi kan snakke om noen reelle geografiske forskjeller eller trender, men Hordaland (nå en del av Vestland) skiller seg ut i antall saker. Det er også påfallende at Oslo og Akershus ikke har flere saker, med tanke på stort religiøst og livssynsmessig mangfold.

\begin{tabular}{|c|c|c|}
\hline \multicolumn{3}{|c|}{ Saksvariasjon og oversikt, per fylke } \\
\hline Oslo og Akershus & Vestfold & Oppland \\
\hline $\begin{array}{l}\text { Svømming, } 2 \text { saker } \\
\text { Skolegudstjenester, } 2 \text { saker }\end{array}$ & Svømming, & $\begin{array}{l}\text { Islam i KRLE, } 1 \text { sak } \\
\text { Skolegudstjenester, } 1 \text { sak }\end{array}$ \\
\hline Buskerud & Telemark & $\emptyset$ stfold \\
\hline $\begin{array}{l}\text { KRLE-fritak, } 1 \text { sak } \\
\text { Svømming, } 1 \text { sak } \\
\text { Homofilli som tema, } 1 \text { sak } \\
\text { Leirskole, } 1 \text { sak } \\
\text { Skolegudstjenster, } 1 \text { sak }\end{array}$ & Skolegudstjenester, 3 saker & $\begin{array}{l}\text { Vandring i Bibelen, } 1 \text { sak } \\
\text { Islam i KRLE, } 1 \text { sak } \\
\text { Fraværsføring, } 1 \text { sak }\end{array}$ \\
\hline Trøndelag & Finnmark & Møre og Romsdal \\
\hline Skolegudstjenester, 2 saker & Fritaksretten generelt, 1 sak & $\begin{array}{l}\text { Buddhisme i KRLE, } 1 \text { sak } \\
\text { Skolegudstjenester, } 1 \text { sak }\end{array}$ \\
\hline Rogaland & Hordaland & Agder \\
\hline $\begin{array}{l}\text { Bibelelsning og juleavslutning, } \\
1 \text { sak } \\
\text { KRLE-fritak, } 2 \text { saker } \\
\text { Homofili, } 1 \text { sak }\end{array}$ & $\begin{array}{l}\text { Skolegudstjenester, } 16 \text { saker } \\
\text { Vandring i Bibelen, } 1 \text { sak } \\
\text { KRLE-fritak, } 7 \text { saker } \\
\text { Evolusjonsfritak, } 1 \text { sak }\end{array}$ & $\begin{array}{l}\text { Fritak for datamaskiner eller inter- } \\
\text { nett, } 3 \text { saker } \\
\text { Kroppsøving, } 1 \text { sak }\end{array}$ \\
\hline Sogn og Fjordane & Hedmark & Nordland \\
\hline Ingen saker & Ingen saker & Ingen saker \\
\hline Troms & & \\
\hline
\end{tabular}


Det samlede saksmaterialet dekker et bredt spekter av tema innenfor norsk skole som helt eller delvis fritak fra KRLE-faget, skolegudstjenestedeltakelse, svømming eller andre aktiviteter i kroppsøving, bruk av digitale verktøy, leirskole, eller enkelttemaer i Naturfag som evolusjon og seksualitetsundervisning. Det er likevel en konsentrasjon av saker knyttet til religionsfaget i grunnskolen. En ser også en tydelig konsentrasjon av henvendelser og saker knyttet til skolegudstjenesteproblematikken. I figur 1 gis det en oversikt over fordelingen av henvendelsene og klagesakene i datamaterialet

\section{Oversikt over fritaksønsker}

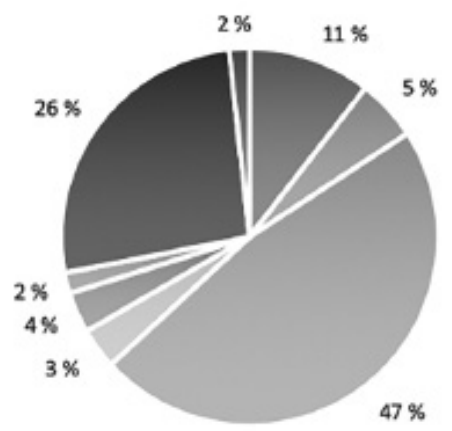

- Svømming og kroppsøving $11 \%$

- Teknologifritak $5 \%$

" Gudstjenestedeltakelse $47 \%$

- Temaet homofili $3 \%$

- Annet $4 \%$

- Leirskolefritak $2 \%$

- Fritak i KRLE $26 \%$

- Evolusjonsteorien (i naturfag) $2 \%$

Figur 1

I det samlede saksmaterialet var det 57 saker, hvorav 33 klager. De aller fleste klagene, 23, ender med avslag. Videre er det 19 saker hvor det gis ut informasjon, stort sett dreier dette seg om henvendelser hvor det etterspørres informasjon. Henholdsvis fem og to av sakene fikk medhold og delvis medhold, men ytterligere fem av sakene er sendt tilbake til kommunen for behandling. I hovedsak skyldes dette at sakene ble sendt til statsforvalteren for tidlig i prosessen eller at det av ulike årsaker ikke var en problemstilling som skulle vært behandlet hos statsforvalteren. Det er videre slik at det i fem av sakene ikke foreligger noe svar fra statsforvalterembetene. Det betyr ikke at det ikke ble sendt et svar på et tidspunkt, men at det ikke var mulig å oppdrive et slikt svar i forbindelse med innhentingen av datamaterialet.

En mulig forklaring for den lave andelen av medhold kan ligge i at fritaksønskene er innrettet slik at foreldrene eller elevene ber om fritak som ville gått på tvers av fritaksretten. Med fritak fra enten hele temaer eller et fag i seg selv. Det er flere eksempler på ønsker om fritak fra hele KRL, RLE, eller KRLE-faget, eller ønsker om fritak fra all undervisning knyttet til Bibelen, fritak fra undervisning om kristendom, eller fra all undervisning i KRLE-faget som dreier seg om noe annet enn kristendom. 
Om skolene skulle ha godkjent disse fritaksmeldingene, ville nok de foresatte eller elevene være fornøyde, men det ville vært problematisk for det fagutbytte som den enkelte skal sitte igjen med etter endt skolegang, og i strid med fritaksrettens utforming. (Se Lomsdalen (2019) for mer om helheten av fritaks-saker.)

\section{Saker som Viser livssynsbaserte tendenser}

I denne artikkelen vil jeg som nevnt fokusere på tendenser i de sakene og kategoriene i det helhetlige datamaterialet der det var en høy andel elever som ble identifisert med en livssynstilhørighet, eller hvor innsenderen av saken oppgav livssynstilhørighet. De tre første kategoriene er kategorier hvor majoriteten av sakene i kategorien har én tydelig livssynsbakgrunn. Den fjerde kategorien er en mer blandet kategori, men hvor mange av sakene har en tydelig livssynstilhørighet.

Skolegudstjenestene, et tema for humanistene?

27 av de totalt 57 sakene i datamaterialet omhandler gudstjenester i skoletiden9. Majoriteten av disse igjen omhandler gudstjenester i forbindelse med julehøytiden, med unntak av en sak knyttet til påskemarkering. Av disse 27 sakene i datamaterialet er det 16 klager og 11 henvendelser. Mange av klagesakene er i stor grad utformet som klager på at det blir gjennomført gudstjenester i skoletiden, og bare sekundært på selve gjennomføringen av gudstjenestene og et eventuelt alternativt opplegg på skolen i samme tidsrom. Dette bidrar nok til å øke antall avslag i denne kategorien. Det er i større grad medhold i de sakene hvor klager i klarere ordelag har påpekt brudd på regelverket for gjennomføring av gudstjenestene. Det er likevel et gjennomgående trekk ved disse sakene at de kommer fra foreldre som enten opplever gudstjenestene i skoletiden i seg selv som problematiske, og/eller som ser på løsningen skolen har valgt som problematisk ut fra behovene til deres familie. Som vi ser ut fra Tabell 2, er det i hovedsak foreldre med humanistisk bakgrunn som klager på gudstjenestene i skolen. Hva de konkret klager på i denne forbindelse, varierer. Det kan være knyttet til informasjonsflyten i forkant av arrangementet, problemstillinger knyttet til øving i forkant, eller informasjonen som er gitt om slik øving, hva slags alternativ elevene får, eller andre forhold. Det kan også være kombinasjoner av de ulike aspektene.

En av sakene skiller seg likevel ut ved at foresatte knytter kapittel 9A i Opplæringsloven inn i problemstillingene knyttet til gjennomføringen av gudstjenester i skoletiden. Denne paragrafen omhandler elevenes psykososiale miljø og de hensynene skolen må ta med bakgrunn i dette. Bruken av denne paragrafen istedenfor og i tillegg til fritaksparagrafen fordrer en annen saksbehandling og

926 saker ble benevnt som skolegudstjenestesaker. Saken Bibellesning og juleavslutning fra Rogaland inkluderes i dette tallet med bakgrunn i klagepunkter og innhold. 
andre vurderinger enn de som gjennomføres for de andre sakene. Det forandrer likevel ikke på utkomme av saksbehandlingen i dette tilfellet. Det avvises fra skolens side at elevens psykososiale læringsmiljø og inkludering i læringsmiljøet er truet av gruppeinndelingen som skjer i forbindelse med gjennomføringen av skolegudstjenesten og øvingen i forkant. Dette opprettholdes av kommunen og fylkeskommunen i løpet av klagesaken. Dette er markant annerledes enn de andre klagesakene i saksfeltet, som knytter seg tettere på fritaksretten i Opplæringsloven og ulike regelverk utledet av dette.

\section{Oppgitt livssynstillhørighet i skolegudstjenester}

\begin{tabular}{|l|c|}
\hline Humanist & 14 \\
\hline Ikke oppgitt & 8 \\
\hline Ikke relevant & 5 \\
\hline
\end{tabular}

Tabell 2: Livssynstilhørighet i skolegudstjenestesaker

Som vi ser av tabell 2, så er det i skolegudstjenestesakene en klar overvekt av saker hvor innsender oppgis å være eller forstås å være humanister. Med det menes en sekulær humanisme som typisk sett i Norge representeres ved Human-Etisk Forbund. Ut fra de årlige debattene knyttet til skolegudstjenestene fremstår ikke dette som overraskende, men det er likevel første gang en slik overvekt har blitt dokumentert. Det er videre åtte saker hvor det ikke er mulig å lese eller tolke ut fra innsendingen hvilken livssynstilknytning innsender har, og det kan foreligge ulike tilknytninger her.

Kroppsøving, kategorien med saker fra muslimske familier I det totale datamaterialet er det seks saker knyttet til kroppsøvingsfaget i skolen. Det er likevel ikke kroppsøvingsfaget som helhet som i det store og hele oppfattes som problematisk. Det er to klare kjennetegn i dette sakskomplekset, og det er 1) at elevene det dreier seg om, er muslimer eller kommer fra muslimske familier og 2) at det er svømmeopplæringen som oppleves som problematisk.

I en av sakene er det likevel helt eller delvis fritak for hele kroppsøvingsfaget som er ønskelig, så det er ikke uten variasjon. De forskjellige sakene er likevel ulike, både med tanke på hvem som har frembrakt saken og hva det spørres om. Det er to klagesaker direkte fra foresatte. De tre øvrige sakene er skoler som ber om råd for å håndtere fritaksønsker fra foresatte eller elever. I sistnevnte kategori finner vi en skole som allerede har kjønnsdelt svømming, kan tilby adskilt dusjing, 
og som informerer om muligheten til å bruke burkini. Skolen mottar på tross av dette en melding fra elev om fritak fra svømming, og spør om råd knyttet til håndteringen av dette. I de to sakene innsendt av foresatte så ender klagesakene i avslag på fritak fra svømmeundervisningen med begrunnelse i at elevene da vil gå glipp av kunnskapsinnhold som de har krav på etter læreplanen. og at skolen ikke har anledning til å frita elevene fra dette.

\section{De særskilt kristne problemstillingene}

Blant sakene som dukker opp i datamaterialet, er det noen fritaksønsker som ikke knytter seg til (K)RL(E)-faget, men som isteden kan omtales som mer tematiske fritaksønsker. Det er også fritaksønsker som har bakgrunn i valget av læremiddel hos skolen. Dette kan være knyttet til enkeltfag, eller mer generelt inn i skolens drift. Når vi tidligere har sett at sakene knyttet til skolegudstjenester i stor grad har kommet fra humanister, og kroppsøvingssakene har dreid seg om muslimske elever, så er disse tematiske sakene i stor grad kommet inn fra foreldre og elever med kristen bakgrunn og/eller tilhørighet. Denne gruppen av saker består av en sak om fritak fra homofili som tema fra Rogaland, en sak om fritak fra evolusjonen fra Hordaland, og tre saker knyttet til læremiddelteknologi fra Agder.

Homofilisaken fra Rogaland er en av de to sakene i datamaterialet med hardest fronter og den tydeligste motstanden mot fellesskapets verdier fra en foresatt med et uttalt kristent verdensbilde, som ikke ønsker at deres barn skal lære om homofili, særlig ikke når undervisningen gis fra en lærer som selv lever i et homofilt ekteskap. Foresatte anerkjenner videre ikke skolens foreslåtte alternative opplegg som godt nok, med bakgrunn i at de som foresatte ikke kan være med på å bestemme innholdet i opplegget, og fordi det er utarbeidet av den samme læreren de ønsker fritak fra undervisningen til. Klagen avvises med bakgrunn i at det ikke kan fritas fra kunnskapsinnholdet i læreplanen, først av kommunens eget klageorgan før den avvises av statsforvalteren i Rogaland.

Saken om fritak fra opplæring om evolusjonen, en sak som kommer fra Hordaland, minner i stor grad om fritaksønskene som blir fremmet i (K)RL(E)sakene, hvor det ønskes fritak fra et tema i et enkelt fag. Foresatte problematiserer i denne saken at lærebøkene i naturfag for sin elev fremstiller evolusjonen som fakta, og «ikkje ein teori og ikkje ein hypotese». Det er i strid med deres religiøse tro, som fremhever skapelsesberetningen i Bibelen. Med tanke på at dette igjen dreier seg om læreplanfestet kunnskapsinnhold, informerer statsforvalteren om at det ikke er mulig å få fritak fra evolusjonen som tema.

Tre av sakene skiller seg ganske betydelig fra de andre gjennom at det ønskes fritak fra bruk av teknologiske læringsverktøy i tråd med innsenders religiøse tro. Med teknologi menes her moderne elektronisk teknologi, gjerne knyttet til internett, men ikke nødvendigvis. Eksempler på slik teknologi er datamaskiner, 
nettbrett og lignende. Det kan argumenteres for at tavlen og blyanten også er teknologi, men det er moderne digital teknologi som det her søkes fritak fra. I noen av sakene inkluderer det også bruk av film i skolens regi. Sakene er relativt like, men det er noen klare forskjeller. I alle tre sakene oppgis et kristent livssyn som grunnlaget for sakene. I den første og den tredje teknologisaken dreier forespørselen seg om grunnskoleelever, mens det i den andre saken som dekkes i datamaterialet, er angående elever i videregående skole. I det første tilfellet starter saken med et avslag fra skole og kommune, og dette opprettholdes saken gjennom. I sak nummer to har det forekommet et tidligere, men ikke-vedlagt, avslag, men hvor dette endres til et fritak etter saksbehandlingen som er dokumentert i datamaterialet. I motsetning til i den tredje saken, hvor det i realiteten har foreligget et fritak gjennom skolens aksept for foreldrenes krav om at deres elever ikke skal bruke datamaskiner og lignende, men hvor skolen i etterkant har kommet frem til at dette ikke burde vært akseptert, og dermed fattet et enkeltvedtak i tråd med fritaksreglene. Dette vedtaket påklages av foreldrene, og statsforvalteren i Agder gir skolen og kommunen rett $\mathrm{i}$ at en ikke kan få fritak for bruk av digitale hjelpemidler i grunnskolen. Faglig og didaktisk sett er det interessant å se at de ulike svarene en får på disse sakene, ligger i hvordan de grunnleggende ferdighetene tolkes i grunnskolen, opp mot hvordan de tolkes i, og i lys av, vurderingsforskriften for videregående skole. For den aktuelle statsforvalteren tilsier dette at selv om en ikke kan innvilge fritak fra bruk av datamaskiner og lignende i grunnskolen, så er det ikke noe $i$ veien for at et slikt fritak kan innvilges i den videregående skolen, selv om statsforvalteren her advarer om at dette kan skape problemstillinger med tanke på eksamensgjennomføringen.

Religionsfaget som potensielt er problematisk for alle Ved siden av skolegudstjenestene, er det religionsfaget i grunnskolen som dukker oftest opp i datamaterialet. Variasjonen i sakene i denne kategorien er også større enn i de andre kategoriene som er omtalt i denne artikkelen og i datamaterialet disse kategoriene er hentet fra, selv om det er innenfor rammen av ett skolefag. Se tabell 3 for en oversikt.

Sett bort fra to rene informasjonsinnhentingssaker så er det i fire av sakene et ønske om fritak fra hele religionsfaget. Ved siden av slike generelle fritaksønsker for hele faget er det flere varianter av ønske om delvis fritak fra faginnholdet i faget. Dette inkluderer en henvendelse hvor det klages på manglende innvilgelse av et fritaksønske for alt faginnhold i KRLE-faget som ikke kan sies å være kristendomskunnskap. Det er videre to henvendelser hvor det er ønskelig å få fritak fra all undervisning om islam. Dette begrunnes i hovedsak med en motstand mot islam, men også med at dette er i strid med deres tro og overbevisning. Uten at dette spesifiseres nevneverdig. 


\section{Fritaksønsker i (K)RL(E)-faget}

\begin{tabular}{|l|c|}
\hline Islam som tema & 2 \\
\hline (K)RL(E)-faget generelt & 7 \\
\hline Buddhisme som tema & 1 \\
\hline Kristendom som tema, helt eller delvis & 3 \\
\hline Opplegget «Vandring i Bibelen» & 2 \\
\hline
\end{tabular}

Tabell 3: Fritaksønsker i $(K) R L(E)$-faget

Vi finner tilsvarende fritaksønsker for kristendom som tema i faget, men det begrunnes svært variert. I en sak bes det om fritak fra alt som har med Bibelen å gjøre. Det oppgis ikke livssynstilhørighet i klagesaken eller begrunnelsen for fritaksønsket, som ville vært interessant sett i sammenheng med en av de andre sakene hvor den foresatte ber om fritak fra undervisning som har med treenighetslæren å gjøre, begrunnet i deres kristne tro. Dette i motsetning til den tredje saken i trekløveret, hvor de foresatte begrunner sitt ønske om fritak fra 40 prosentpoeng av kristendomsdelen i faget med henvisning til at de er livssynshumanister. Fritaksønsket begrunnes konkret $\mathrm{i}$ et ønske om likebehandling av religionene i faget etter innføringen av KRLE i 2015.

Ytterligere to av sakene skiller seg litt ut fra de andre kristendomsrelaterte sakene ved at det ikke blir klaget på eller blir bedt om fritak for kristendom som tema i undervisningen, men at det blir klaget på et konkret undervisningsopplegg. Sakene er fra ulike år og ulike fylker, men er rettet mot det samme undervisnings-

Livssynstilhørighet i (K)RL(E)-sakene

\begin{tabular}{|l|c|}
\hline Humanister & 3 \\
\hline Muslimer & 2 \\
\hline Kristne & 3 \\
\hline Ikke relevantis & 1 \\
\hline Ikke oppgitt» & 6 \\
\hline
\end{tabular}


opplegget. «Vandring i Bibelen» er et undervisningsopplegg laget av Bibelselskapet for å gi elevene kunnskap om bruk av Bibelen og kristendommens historie (Holien, 2020, s. 196). I klagesakene klages det både på gjennomføringen av selve opplegget, som de foresatte oppfatter som forkynnende, men også på hvordan bibelutdelingen til elevene har blitt gjennomført. Her har elevene fått hver sin bibel istedenfor å få låne, slik tilfellet er med andre skolebøker. En lignende sak foreligger også, hvor det klages på at det ble gjennomført meditasjonsøvelser som en del av undervisningen om buddhisme. Det ble begrunnet med at dette opplevdes som deltagelse i utøvelse av en religion de selv ikke tilhørte.

Som vi ser i tabell 4, så er den største gruppen av saker i denne kategorien de sakene hvor innsender ikke oppgir livssynstilhørighet. Samtidig er argumentasjonen i en del av disse sakene tydelig, og kunne ha vært plassert inn i en av livssynskategoriene. Det har jeg valgt å ikke gjøre. Det fremkommer likevel tydelig at (K) RL(E)-faget er problematisk for foresatte og elever fra både kristne, muslimske, og humanistiske hjem. Det er på mange måter interessant, men langt ifra uventet.

\section{UENIGHETSFELLES SKAPET}

Religionssosiolog Lars Laird Iversen har definert og fremmet begrepet uenighetsfellesskapet som en ramme for å forstå virksomheten vi driver med i skolen. Primært sett inn mot religionsfaget, men modellen fremmes også opp mot skolen og samfunnet generelt som forståelsesmodell for hvordan vi skal forstå uenighetene, fellesskapet, og den nødvendige rammen for samhandling (2014). Når vi i denne sammenhengen skal se på uenighetsfellesskapet og hvordan det kan skape en ramme for å forstå fritaksmeldingene, så er det som et pedagogisk klasseromsideal (Iversen, 2017, s. 101).

Iversen definerer «et uenighetsfellesskap er en gruppe mennesker med ulike meninger som deler en felles utfordring eller et felles problem». Denne gruppen mennesker har $\mathrm{i}$ en idealtype blitt kastet sammen med tilfeldighet (Iversen, 2017, s. 103), noe som ofte stemmer for klasser i en nærskole. I denne skolesituasjonen skal elevene læres opp til etisk refleksjon og gode handlinger, basert på de verdiene vi finner i opplæringsloven og andre formålsdokumenter, men det skal også forene oss (Iversen, 2017, s. 105). Samtidig som Norge etter FNs konvensjon om sivile og politiske rettigheter artikkel $18.4 \mathrm{er}$ forpliktet på at foreldrene har rett til å oppdra barna etter sin overbevisning (FN, 1966; Hansen, 2018, s. 104; 106). Som et samfunn kan Norge også fremstå som et slikt uenighetsfellesskap, med mennesker som mer eller mindre tilfeldig har blitt plassert innenfor den samme konteksten, med mange felles referanser og verdier, og koblet sammen som en gruppe, men hvor det likevel er store forskjeller i verdier, holdninger, og synspunkter (Iversen, 2017, s. 107-108).

Skolen blir i denne sammenhengen og innenfor tanken om å være et uenig- 
hetsfellesskap den viktigste treningsarenaen for fellesskapet ute i storsamfunnet. Uenighet er ikke nødvendigvis en trussel, men det å undertrykke uenighet og motsetninger, og å skjule dem, kan skape utrygge klasserom og deretter polarisering eller utrygghet i samfunnet (Iversen, 2017, s. 101). For at vi skal kunne leve sammen i dette uenighetsfellesskapet, med de ulikhetene som eksisterer på bakgrunn av religion, livssyn, og politiske holdninger, er vi avhengig av at vi har kunnskapen om hverandre slik at vi kan forstå hverandre. Den viktigste arenaen for å lære om dette er i Norge den offentlige skolen, hvor vi også finner de fleste elevene (Skeie, 2018, s. 47).

Tanken om skolen som et uenighetsfellesskap er forståelsen for at en skole er et samlingssted for det mangfoldet som finnes i samfunnet, og hvor det må være en forståelse for at mangfoldet i skolen skaper et behov for å være et noe annet enn et verdifellesskap eller et enighetsfellesskap (Iversen, 2017, s. 102). Iversen advarer mot to ulike grøfter en kan havne i ved å fokusere på at skolen skal være et verdieller enighetsfellesskap. Den første grøften er at man automatisk kan ende opp med å se på uenighet som en dypereliggende verdi- eller kulturkonflikt, og dermed skape mer eller unødvendig polarisering. Den andre grøften en som skole kan havne i, er at man undertrykker uenighet fordi ansatte i skolen kan være redde for å krenke eller såre elever (og foreldre) (Iversen, 2017, s. 102). Ved å anerkjenne at Norge og klasserommet er ulike former for uenighetsfellesskap, åpner det for at vi kan bruke klasserommet som den øvingsarenaen Iversen ser for seg til å skape «uredde og problemløsende medborgere, i stand til å håndtere reell uenighet, både innen og mellom religiøse tradisjoner og fellesskap» (Iversen, 2017, s. 116).

\section{LIVSSYNSBASERT MOTSTAND MOT SKOLEN SOM UENIGHETSFELLESSKAP}

Hvis vi skal se på klasserommet og skolen som et uenighetsfellesskap, hvor en skal få opplæring i og trygghet til å diskutere, snakke om, og leve i uenighet, så innebærer det at en må være villig til å være nettopp i den uenigheten og å leve med den. Dette gjelder kanskje særlig for de situasjonene hvor det omhandler de mest grunnleggende verdiene, eller hvor det er sammenhenger som kan sies å være på det mest grunnleggende nivået når det kommer til fellesskap. Eksemplene som er trukket frem i denne artikkelen, utfordrer på mange måter dette fellesskapet. Aller tydeligst blir dette når forelderen i saken om homofili fra Rogaland ønsker å bytte ut læreren som underviser om homofili, fordi læreren selv er homofil og lever i likekjønnet ekteskap. Foresatte i denne saken ønsker også å kunne være med på å bestemme diskusjonene som foregår i klasserommet. Ved siden av å være i strid med metodefriheten som lærere fremholder i klasserommet, så ville dette begrenset de mulighetene en som lærer har til å skape en trygg og god ramme hvor ulike meninger kan brytes mot hverandre. 
Motstanden fra de i saksdokumentene som identifiserer seg som humanister, mot skolens ordning for gudstjenester i skoletiden, plasserer på samme måte disse foreldrene og elevene utenfor fellesskapene som utgjør klassen og skolen. Utenforskapet skjer ved at disse elevene får et alternativt opplegg som i disse sammenhengene plasserer dem på utsiden av fellesskapet. Det samme utenforskapet eller eksklusjonen kan en argumentere for at rammer andre grupper som plasseres utenfor i de samme situasjonene, som barn av medlemmer i Jehovas vitner. Samtidig er det viktig å understreke at det ikke er noen slike saker i datamaterialet. Det er også mulig å argumentere for at en annerledes innretning på denne ordningen, hvor en deltok i aktivitetene til flere tros- og livssynssamfunn enn i dag og, hvor ett trossamfunn ikke lenger har fokus, ville kunne gjøre ordningen mindre problematisk for flere av de som i dag opplever den som problematisk. Det kunne ha betydd at den ville vært problematisk for langt flere også, ut fra argumentasjonen i enkelte av (K)RL(E)-sakene. Buddhismesaken fra (K)RL(E)materialet, hvor det oppleves som problematisk for et foreldrepar at deres barn er med på meditasjon som en del av et undervisningsopplegg om buddhismen, vitner om muligheten for en økt motstand. Det ville kanskje likevel i større grad bidratt til at ordningen ville kunne bidra til en større grad av forståelse mellom ulike grupper i uenighetsfellesskapet. Anker med flere har vist at ungdom i liten grad deltar i religiøse aktiviteter. De fleste har heller liten eller ingen interesse for religiøse aktiviteter (Anker m.fl., 2018, s. 63).

Det er litt vanskeligere å sette svømmekategorien og motstanden mot skolens svømmeopplæring inn i uenighetsfellesskapsdiskusjonen. Den hører på mange måter ikke inn der. Samtidig, når en ser på argumentene som føres mot den felles svømmeundervisningen, og når en ser reaksjonene som kommer mot kjønnsdelt svømming eller fritak for svømming i media, er det tydelig at det her handler om en verdikonflikt. Der hvor dette handler om kvinners ærbarhet og samhandling mellom kjønnene på den ene siden, så handler det om kjønnslikestilling og fellesskapet på den andre siden (Budalen og Tveit, 2017; Thorsen og Sandaune, 2017; Ravn, 2015).

I kategorien for $(\mathrm{K}) \mathrm{RL}(\mathrm{E})$-sakene blir problemstillingen knyttet til det å stille seg utenfor skolen som et fellesskap, ekstra tydelig. I flere av sakene handler det om nettopp en uvillighet til å la sine barn få en opplæring i noe som strider med foresatte eller elevenes overbevisning, tro, eller livssyn. De ønsker i flere tilfeller ikke at den informasjonen skal gis til elevene, enten i det hele tatt eller på en måte som de selv ikke kan kontrollere eller godkjenne. I noen tilfeller brukes også fritaksretten som et politisk virkemiddel mot et fag som de ikke støtter. Uavhengig av hvordan det legges frem, så ville disse fritaksønskene, om innvilget, nettopp vært med å utfordre fellesskapet i skolen, enten en ser på det som et uenighetsfellesskap eller ikke. 
Et spørsmål blir likevel viktig når vi ser at foresatte på denne måten kan sies å utfordre det uenighetsfellesskapet som skolen er: Hva ved skolens virksomhet er unødvendige utfordringer av uenighetsfellesskapet i seg selv? Er det praksiser som skolen har, som legger føringer, eller rammer for skolens virksomhet som i seg selv skaper for store utfordringer for skolen som et rammeverk, enten vi ser på skolen som et enighets- eller uenighetsfellesskap? Å besvare dette krever nok mer forskning, men det er likevel verdt å stille seg disse spørsmålene, opp mot målsetningen om at det er foreldrene som har råderetten på sine barns oppdragelse, samtidig som skolen skal gi en opplæring i tråd med noen verdier. Dette kan innebære at det er elementer som skal tas ut av skolen for å gis som opplæring hjemme, eller at skolen skal vri på de oppleggene som oppleves som problematiske for store enkeltgrupper. Her er det nok også en forskjell på de grunnleggende forutsetningene i en problemstilling. Det er nok vanskeligere for skolen som institusjon å skulle unnlate å snakke om homofili som noe normalt eller livssynslikestilling som noe ønskelig, enn det er å skulle legge opp til kjønnsdelt svømmeundervisning, endre gudstjenesteordningen i skolen, eller legge opp til mindre bruk av svinekjøtt i Mat og helse-faget. Det er likevel vanskelig å finne entydige svar på disse problemstillingene.

\section{Avslutining}

I majoriteten av henvendelsene og klagene er det ikke oppgitt hvilken livssynstilhørighet innsenderen har. Dette tilsvarer 21 saker i det helhetlige datamaterialet. Det er også videre noen saker hvor det er regnet som irrelevant, for eksempel der hvor henvendelsen kommer fra en journalist, skole, eller forsker. Som tabell 5

\section{Oppgitt eller kjent bakgrunn på innsender}

\begin{tabular}{|l|c|}
\hline Muslim & 6 \\
\hline Ikke oppgitt & 21 \\
\hline Humanist/ateist & 16 \\
\hline Kristne & 8 \\
\hline Ikke relevant & 6 \\
\hline
\end{tabular}


viser, er det mange saker hvor livssynsbakgrunnen oppgis eller hvor det er kjent livssynsbakgrunn hos innsender. Det er i stor grad humanister som står for mange av sakene. Dette finner vi igjen i gudstjenestekategorien hvor nettopp mange av disse sakene er blitt plassert. Det er enkelte saker også blant (K)RL(E)-sakene, men det er blant gudstjenestegjennomføringen hovedtyngden av saker befinner seg. Etter humanistene kommer kristne og muslimer med henholdsvis åtte og seks saker. Det vil kunne være avvik her fra tidligere beskrivelser ettersom saker som omhandler muslimer, har blitt sendt inn av skoler, og innsenderen dermed ikke er kategorisert i tråd med elevens eller familiens livssyn. Med tanke på at humanister og muslimer utgjør få prosentandeler (SSB, 2019) av Norges organiserte livssynstilhørighet, er de uproporsjonalt høyt representert blant sakene i denne undersøkelsen. Dette kan være med på å si noe om fritaksrettens funksjon og viktigheten av at den fungerer som en sikkerhetsventil for livssynsminoriteter inn $i$ en fellesskole bygget på den historiske majoritetens premisser.

Ut fra datamaterialet ser vi at fritaksretten er et variert og bredt felt å arbeide med og undersøke. Vi kan se at det er noen tema som utpeker seg særlig som problematiske for en del foreldre fra ulike grupper, og at det er noen klare livssynsforskjeller i hvilke sider av norsk skole som oppfattes som problematisk for de ulike gruppene. Samtidig skaper dette situasjoner som kan være problematiske å håndtere for lærere og skoler når foresatte og elever på denne måten velger å stille seg utenfor skolen som et uenighetsfellesskap. Det skaper et behov for mestringsog håndteringsstrategier fra skolens side som vi i liten grad har oversikt over. Det er også tydelig at vi vet lite om hvordan fritaksønskene og gjennomføringene av dem påvirker norske klasserom, og om de påvirker klasserommene i det hele tatt. Det er et betydelig behov for mer kunnskap om praktiseringen av fritaksretten slik den er innrettet i norsk skole.

\section{LitTERATUR}

Andersland, Inge. 2019. Religion education, religious and national identity, and the purpose of education. An idea analysis of two debates concerning RE in the Norwegian Storting. [Doktoravhandling, MF vitenskapelig høyskole].

Andreassen, Bengt-Ove. 2012. Religionsdidaktikk. En innforing. Universitetsforlaget. Anker, Trine, Lippe, Marie von der, og Undheim, Sissel. 2018. «Ungdom og religion: tradisjon, nyskaping og individuelle valg.» I: Schjetne, Espen og Skrefsrud, Thor-André (red.), Å vare laerer $i$ en mangfoldig skole (s. 58-73). Gyldendal.

Budalen, Andreas og Tveit, Josef Benoni Ness. 2017, 15. juni. Kjønnsdelt undervisning er lovlig. NRK. https://www.nrk.no/nordland/_-kjonnsdelt-undervisning-er-lovlig-1.13560847. 
Dalane, Marte Holmeide. 2014. Mer eller mindre haram? Unge, norske muslimers forhold til musikk og musikkundervisningen i skolen. [Masteroppgave, Det teologiske Menighetsfakultet]. http://hdl.handle.net/11250/220027.

Europarådet. 1952. Protocol 1 to the European Convention for the Protection of Human Rights and Fundamental Freedoms. https://lovdata.no/lov/1999-05-21-30/ emke/p1/a2.

FN. 1966. Den internasjonale konvensjonen om sivile og politiske rettigheter. https:// lovdata.no/dokument/NL/lov/1999-05-21-30/KAPITTEL_sp.

Forvaltningsloven. 1967. Lov om behandlingsmåten i forvaltningssaker (LOV-196702-10). https://lovdata.no/dokument/NL/lov/1967-02-10/.

Haakedal, Elisabeth 2000. "Det er jo vanlig praksis hos de fleste her ...". Religionslarerrolle, livstolkning og skolekulturell ritualisering. En religionspedagogisk studie av grunnskolelareres handlingsrom på 1990-tallet. [Doktorgradsavhandling, Universitetet i Oslo].

Hansen, Ole Henrik Borchgrevink. 2018. «Barns beste i en mangfoldig skole.» Schjetne, Espen og Skrefsrud, Thor-André (red.), À vaere laerer $i$ en mangfoldig skole (s. 96-110). Gyldendal.

Hovdelien, Olav. 2011. Den multikulturelle skolen - hva mener rektorene? [Doktorgradsavhandling, Universitetet i Agder].

Hovdelien, Olav. 2019. Religion og samfunn. En innforing. Fagbokforlaget.

Holien, Anny. 2020. Bibelkurs for 5. trinn. Prismet, 71 (2), s. 195-203. https://doi. org/10.5617/pri.8012.

Iversen, Lars Laird. 2014 Uenighetsfellesskap. Blikk på demokratisk samhandling. Universitetsforlaget.

Iversen, Lars Laird. 2017. «Uenighetsfellesskap. Kan skolen være et treningsrom for offentlig uenighet?» I: Lippe, Marie von der og Undheim, Sissel (red.), Religion i skolen (s. 101-116). Universitetsforlaget.

Lied, Sidsel. 2008. «KRL-faget i Strasbourg. Presentasjon av dom og dissens i EMD og skisse av en mulig vei videre.» Norsk Teologisk Tidsskrift, 109 (1), s. $55-71$.

Lippe, Marie von der. 2017. «Fritak for hvem og for hva?» I: Lippe, Marie von der og Undheim, Sissel. (red.), Religion i skolen (s. 87-100). Universitetsforlaget.

Lippe, Marie von der. 2018a. «The Right to Exempted.» I: Rydving, Håkan og Olsson, Stefan (red.), Religion, Law, and Justice (s. 145-172). Novus forlag.

Lippe, Marie von der. 2018b. «"It's complicated". Et historisk blikk på forholdet mellom religionsvitenskap og religions- og livssynsfagene i norsk skole.» Chaos, 70 (2), s. 121-142).

Lomsdalen. 2019. Den besverlige fritaksretten. Om klagesaker og henvendelser gjort til fylkesmannsembetene knyttet til Oppleringsloven \$2-3a. [Masteroppgave, Universitetet i Bergen]. https://hdl.handle.net/1956/21167. 
Løvland, Anne og Repstad, Pål. 2019. Mellom forkynning, kulturarv og inkludering. Skulegudstenester før jul. Kirke og Kultur, 124 (3), s. 207-223. https://doi.org/10.18261/issn.1504-3002-2019-03-02.

NOU 2019:23 Ny opplaringslov.

Opplæringslova. 1998. Lov om grunnskolen og den vidaregåande opplaringa. (LOV-1998-07-17-61). Hentet fra https://lovdata.no/dokument/NL/ lov/1998-07-17-61.

Ravn, Lars. 2015, 10. april. «Plikter å tilrettelegge for kjønnsdelt svømming.» Telemarksavisa. https://www.ta.no/undervisning/svommeopplaring/ oppvekstsjef/plikter-a-tilrettelegge-for-kjonnsdelt-svomming/s/5-50-60088.

Skeie, Geir. 2018. «Religioner, livssyn og interkulturell opplæring.» I: Schjetne, Espen og Skrefsrud, Thor-André (red.), Á vaere larer i en mangfoldig skole (s. 39-56). Gyldendal.

Statistisk Sentralbyrå. 2019. Trus- og livssynssamfunn utanfor Den norske kyrkja. Statistisk Sentralbyrå. https://www.ssb.no/kultur-og-fritid/statistikker/ trosamf.

St.meld. nr. 32. 2000-2001. Evaluering av faget Kristendomskunnskap med religionsog livssynsorientering.

Thorsen, Bente og Sandaune, Lill Harriet. 2017, 01. juni. «Nei til kjønnsdelt undervisning!» Dagbladet. https://www.dagbladet.no/kultur/nei-til-kjonnsdelt-undervisning/67619325.

Øverlien, Mina og Kjørven, Ole Kolbjørn. 2019. «Juleavslutninger i skolen - et inkluderende fellesarrangement?» Prismet, 70 (4), s. 343-360. https://doi. org/10.5617/pri.7515. 